In case of $M$. sanborni, for example, I found the addition of soap enabled either Sulphate of Nicotine or Nico-Fume to kill well down to 1. part in 800 or even 1,000 of water. The action of the soap seems to be merely to cause the fluids to wet and spread out upon the surface of the bodies of the lice instead of accumulating in drops and running off.

\title{
INSECT NOTES FROM NEW HAMPSHIRE FOR 1909
}

By E. Dwight Sanderson, Durham, N. H.

Insect life was unusually abundant and injurious in New Hampshire in 1909.

Aphids were unusually common during the late spring and early summer. Aphis pomi did much more injury than usual, especially to young apple trees and there were numerous complaints of its work. Aphis setarice was common on cherry and plum thruout the state, curling the foliage very badly.

The pear leaf blister mite (Eriophyes pyri) has been common on pear for many years but has never been reported as a pest of apple until the past season in which we have received several reports from different parts of the state. It is interesting that New York State seems to set the style in insect pests as well as in other matters and that the neighboring states soon have the same troubles. The only explanation of the appearance of this mite in its new rôle as an apple pest is that suggested by Professor Parrott to me which may be due to dry seasons, of which we have had three in New Hampshire.

The apple leaf hopper (Empoasca mali LeB.) has been remarkably abundant and has caused a speckling of the apple foliage by a seeming destruction of the chlorophyl sap. I have not been able to observe any particular injury to old trees altho the numbers of insects have caused our fruit growers some alarm.

The spittle insect on pine (Aphrophora parallela) was very abundant, as in 1908, but we have been unable to relate its work in any way to the so-called pine blight. Its work is of no economic significance so far as we have been able to observe. The Fall web-worm and other caterpillars affecting apples in late summer have continued to be abundant as during the last two seasons.

The antlered maple worm (Heterocampa guttivitta) devastated the same territory as in 1908 and its injury was fully as severe. We had hardly expected to see severe injury by it this year but in view of the repetition of the outbreak this year we can see no reason why it may not be expected to be destructive in 1910. The trees in the worst 
infested area have now been stripped of their foliage two years. Last year most of them leaved out in the fall but this year $\mathrm{I}$ am informed that many of them have failed to leaf out again. Undoubtedly many have already been killed and should they be stripped again immense areas of hard wood will undoubtedly be killed. Should this occur it would be the most serious injury to forest trees by a leaf eating caterpillar of which we know in this country. So far no parasites have been observed which are doing very effective work against the pest but the ground beetles, particularly Calosoma frigida, were present in large numbers and undoubtedly did very effective work both as larve and adults. The striped maple worm (Anisota rubicunda) and the spiny oak caterpillar (Anisota stigma) were again abundant on maple and oak over the same territory affected by the antlered maple worm.

For the last two years the elm leaf beetle (Galerucella luteola) has been becoming more abundant in the cities in the southeastern part of the state. The present year many of the trees in Newmarlset, Exeter, Dover, Manchester and Nashua were entirely stripped of their foliage where they had not been sprayed. Another season effective work will undoubtedly be done against the pest by spraying. The unusual prevalence of this insect so far north can only be accounted for by our exceptionally dry summers and the rather open winters of the last two years. It is beyond its northern range as previously known to us and we shall expect to see it disappear and only break out under similar climatic conditions in the future. It may be possible, however, as Dr. H. T. Fernald has suggested, that it, as well as some other insects, will adapt themselves to a more northern habitat.

The brown-tail moth (Euproctis chrysorrhoea) is increasingly abundant in the more recently infested territory but altho we have made no careful survey of its spread, it seems to be spreading but very slowly toward the Connecticut Valley and to have reached its northern limit as we have previously predicted. Practically no serious injury is done by the insect in most of the territory north of Lake Winnipesaukee. In the worst infested region, as for instance in Durham, over 95 per cent of the caterpillars were killed off by a fungous disease altho there was hardly a normal rainfall. With normal rainfall in the spring and late summer the pest will undoubtedly be greatly reduced in numbers in the future. Spraying with arsenate of lead to destroy the young caterpillars during the first two weeks in August has been found exceedingly effective and cheap for both apple and shade trees, both in our own work and in that of our fruit growers.

The gipsy moth (Porthetria dispar) continues to spread and we 
regret to state that except for the work being done by the U. S. Department of Agriculture that practically nothing is being done for its control either by the enforcement of the law or by the education of the people. The outlook for any possible control of the gipsy moth in southern New Hampshire is exceedingly dark and we are inclined to the belief that the only result possible is a very general and widespread destruction of the timber in southern New Hampshire, particularly the white pine, upon seeing which the people will probably awalre to the necessity of handling such problems in a thoro going and scientific manner. The boll weevil has been a great blessing to Teras. We have already seen a considerable benefit from the brown-tail moth in New Hampshire in compelling the care of neglected orchards and the destruction of scattering trees. It is quite probable that the gipsy moth may be the means of arousing an appreciation of the value of our timber and shade trees and the rational growth and. care of farm woodlots.

\section{INSECTS NOTABLY INJURIOUS IN LOUISIANA DURING 1908 AND 1909}

By Arthur H: Rosenferd, Baton Rouge, La

This article is prepared as a sort of continuation of the article by Mr. Wilmon Newell and the author, published in Volume 1 of the Journal of Economic Entomology. ${ }^{1}$ We realize that a paper of this nature is not of particular interest at a meeting of this kind, nor does it require a great amount of scientific acumen to prepare such an article; however, we think that the value of such papers for reference use justifies their presentation here.

\section{Cotton Insects}

Practically the entire cotton area of Louisana, embracing some 34,000 square miles, is now infested with the boll-weevil, Anthonomus grandis Boh. As a result, the cotton acreage of the state has been much reduced, and this season Louisiana has made the shortest crop in all of her history - about 273,000 bales, against 517,000 in $1908,610,724$ in 1907, and 769,222 in 1906.

The boll-worm, Heliothis obsoleta Fab., has been, as usual, present in all parts of the state, but has not been particularly severe during the past two years.

1"A Brief Summary of the More Important Injurious Insects of Louisiana," Jour. E. E., Vol. I, page 150. 